\title{
Defining interdisciplinary collaboration based on high school teachers' beliefs and practices of STEM integration using a complex designed system
}

\author{
Hui-Hui Wang ${ }^{1 *}$ (D), Mingla Charoenmuang ${ }^{2}$, Neil A. Knobloch ${ }^{3}$ and Roger L. Tormoehlen ${ }^{4}$
}

\begin{abstract}
Background: Teachers' beliefs play an important role in how teachers think about how students learn, and how content should be organized and taught. Integrated STEM is pushing the boundaries of some of the traditional assumptions in education-disciplined-based courses, courses taught independently by teachers, standards and content-driven, and no collaborative planning time for teachers. Six teachers, located in two high schools, participated in a year-long program to develop interdisciplinary collaboration to implement integrated STEM learning in their courses. A qualitative instrumental case study of the two teams of teachers was conducted to gain insights and understandings of the teachers' beliefs and instructional practices of STEM integration through interdisciplinary approaches in a complex system (i.e., hydroponics).
\end{abstract}

Results: Themes regarding features, beliefs and practices, and challenges emerged from cross-case analysis of the teachers' stories, which resulted in two interdisciplinary collaboration models, multi-classroom and extracurricular activity, from each of the teams at each of the two high schools. Multi-classroom and extracurricular activity models had some resemblances, but also had differences. Both cases had the same goals to use real-world problems to help students see STEM connections, learn STEM knowledge and skills, and apply STEM knowledge and skills to solve real-world problems.

Conclusions: Based on teachers' beliefs and their interdisciplinary STEM collaboration practices, three components were identified. Team size, teaching goal, and collaboration structure highly affect a successful interdisciplinary STEM collaboration model in high school settings. The study also contributes to expend the concept of a continuum of STEM approaches to curriculum integration, disciplinary, multidisciplinary, interdisciplinary, and transdisciplinary (Vasquez, Sneider, \& Comer, STEM lesson essentials: Integrating science, technology, engineering, and mathematics, 2013), and provides frameworks for structuring a successful interdisciplinary collaboration model in high school settings.

Keywords: Interdisciplinary collaboration, Teacher beliefs and practices, STEM integration, High school

\section{Introduction}

Teachers are expected to teach students how to solve problems that they will face in their careers as scientists and engineers. However, real-world problems in a humanbuilt world are often interdisciplinary in nature and occur in complex systems (Dym, Agogino, Eris, Frey, \& Leifer, 2005). These problems, usually interdependent of the

\footnotetext{
*Correspondence: huiwang@purdue.edu

'Department of Agricultural Sciences Education and Communication, Purdue University, 915 W. State Street, Lilly Hall, 3-223, West Lafayette, IN 47907, USA Full list of author information is available at the end of the article
}

system, require sophisticated problem-solving skills, innovative and complicated solutions, and involvement of multiple components (Levy, 1992; Richardson, Cilliers, \& Lissack, 2001). For example, when solving a real-world food deficit problem using hydroponics to increase vegetable production and overcome technical difficulties (e.g., lighting, and water and nutrition supply), environmental and social impacts should also be taken into consideration when designing the system. Teaching systems thinking when solving problems aligns with developing twenty-first century career skills, and helps students learn 
how to cope with complexity, and make scientifically and mathematically sound decisions to solve a real-world problem in a complex designed system (Dym et al., 2005). Yet, teachers are typically not prepared to teach students how to solve problems using systems and interdisciplinary thinking.

Professional societies, such as the American Society for Engineering Education (ASEE), National Academy of Engineering (NAE), and the National Research Council (NRC), call for new educational approaches that focus on hands-on, interdisciplinary, and socially relevant aspects of science, technology, engineering, and mathematics (STEM) to improve K-12 STEM education. In addition, the Next Generation Science Standards (NRC, 2013) and the Framework for K-12 Science Education (NRC, 2012) enumerated core disciplinary ideas, crosscutting concepts, and science and engineering practices for grades K-12. This current educational reform movement provides a new vision of STEM education to help students make sense of the fragmented and departmentalized knowledge that is typically taught in disciplinary silos. As defined by the National Research Council, STEM integration is "working in the context of complex phenomena or situations on tasks that require students to use knowledge and skills from multiple disciplines" (NAE \& NRC, 2014, p. 52). Consequently, integrated STEM teaching approaches should attempt to mirror solving a real-world problem in a complex designed system, where students use knowledge and skills from multiple disciplines that relate to their everyday lives (Bryan, Moore, Johnson, \& Roehrig, 2016; Bybee, 2010, 2013; English, 2016; NAE \& NRC, 2014; Wang \& Knobloch, 2018).

Although STEM integration encourages interdisciplinary collaboration, teachers are traditionally trained to teach domain-specific knowledge. There is a growing concern regarding how teachers trained in one of the STEM domains are not equipped to incorporate less familiar practices into their teaching. In addition, high schools are structured in ways that continue to encourage teachers to stay in their teaching disciplinary silos (Boyd, 2017). Regardless of the core discipline(s), most scholarship in interdisciplinary integrated STEM is focused on elementary and middle school level instruction (e.g., Cantrell, Pekcan, Itani, \& Velasquez-Bryant, 2006; Capobianco, DeLisi, \& Radloff, 2017; Donegan-Ritter \& Zan, 2018; Guzey, Ring-Whalen, Harwell, \& Peralta, 2019; Hammack \& Ivey, 2017; Mehalik, Doppelt, \& Schuun, 2008; Tuttle et al., 2016). Various challenges have been reported to hinder STEM interdisciplinary instruction in previous research studies (e.g., Baker, Bunch, \& Kelsey, 2015; Graves, Hughes, \& Balgopal, 2016; Lesseig et al., 2017). As a result, more research studies are needed to investigate the importance of using interdisciplinary STEM as teaching approaches in high school settings.

\section{Review of Literature}

Teacher's beliefs refer to beliefs related to teaching including knowledge, students, and instruction (Buehl \& Beck, 2014). Beliefs shape who teachers are as individuals (Caudle \& Moran, 2012; Fang, 1996) and are influential in teachers' decision-making, thinking, and practice in classrooms practices (Caudle \& Moran, 2012; Fang, 1996; Pajares, 1992). One of the underlying assumptions to understand teachers' thought processes, especially beliefs, is that it would lead to understanding what guides their classroom behaviors (Fang, 1996; Lumpe, Haney, \& Czerniak, 2000; Nespor, 1987). Although beliefs are a difficult construct for empirical investigation because they tend to be philosophical or spiritual, beliefs are stronger predictors of behaviors than knowledge because they are centric to one's identity and more difficult to change (Pajares, 1992). However, the relationships between teachers' actions and their effects are not always considered as linear. For example, teachers teach topics that they believe are interesting, but their students may find the topics dreary (Farrell \& Ives, 2015). Teachers may believe in learner-centered teaching, but their practices may be didactic in nature (Lim \& Chai, 2008; Liu, 2011). Many factors, internal and external (Buehl \& Beck, 2014), shape teachers' beliefs and influence their practices. These factors include disciplinary subculture (Fang, 1996; Mansour, 2009), knowledge, skills, and abilities (Buehl \& Alexander, 2001, 2006; Buehl \& Beck, 2014; Hofer, 2000; Yadav \& Koehler, 2007); teacher preparation programs (Rice \& Kitchel, 2017); time and resources (Mansour, 2009; Raymond, 1997); curriculum and standards (Buehl \& Beck, 2014); years of teaching experiences (Lumpe et al., 2000); school and classroom environments; and education-related policies (Buehl \& Beck, 2014; Lumpe et al., 2000). In short, teachers' beliefs and practices are not context-free, but situational.

As for teachers' beliefs and practices of STEM integration, many teachers consider STEM integration as the use of all four disciplines, but they have no clear understanding of the enactment of integration (Breiner, Harkness, Johnson, \& Koehler, 2012). Research has shown that teachers see connections between STEM disciplines (Wang \& Knobloch, 2018; Wang, Moore, Roehrig, \& Park, 2011) and believe that integration helps students connect school learning with real-world problems (Hargreaves \& Moore, 2000; Mason, 1996; Schlechty, 1990). Furthermore, integrated STEM instruction can increase student engagement and problem-solving abilities (Kendall \& Wendell, 2012). However, teachers also report challenges 
in integrating other STEM subjects, because they lack the content and pedagogical knowledge for effective integration (Baker et al., 2015; Graves et al., 2016; Kurup, Li, Powell, \& Brown, 2019; Lehman, 1994; Mason, 1996). Teachers also tend to focus on disciplinary content rather than cross-disciplinary ideas (McNeill \& Knight, 2013), perhaps because they have difficulty facilitating disciplinebased learning while also giving a central role to real-life problems and global issues (Bybee, 2013). Teachers face barriers to integrating technology and engineering due to their students and their lack of knowledge and skills in these areas (Bybee, 2013). Therefore, teachers often focus on science and math with little integration of technology or engineering (Bybee, 2010; Guzey, Tank, Wang, Roehrig, \& Moore, 2014; Moore et al., 2014; Smith, Rayfield, \& McKim, 2015). In regard to interdisciplinary STEM education, Weinberg and McMeeking (2017) studied science and mathematics, and identified barriers that hindered interdisciplinary collaboration. These barriers included standards, level of control, assessment fit, teacher knowledge, skills and abilities, and collaboration. Their results echoed Buehl and Beck's (2014) findings that teachers' experience and knowledge, as well as classroom, school, and district factors all have influence on their beliefs and practices.

In the 1960s, interdisciplinary teaming was an instructional innovation for school improvement aimed to reduce teacher isolation, foster interdependence, and promote collegiality and collaboration (Murata, 2002). Since then, team teaching has been a strategy used across the USA for various purposes, including to gain control of large groups of students and to interject variety into the single-subject, single-teacher classrooms (Murata, 2002). Definitions of interdisciplinarity generally contain the feature of integrating two or more academic disciplines together. In interdisciplinary teaching, it commonly involves teachers focusing on making connections between subject areas obvious for students to see (Sdunekv \& Waitz, 2017; St. Clair \& Hough, 1992). Instead of curricula being fragmented, these connections make learning more natural and foster deep conceptual understanding (Capraro \& Jones, 2013). Interdisciplinary teaching emphasizes application and synthesis of content and skills, and the interdisciplinary content promotes meaningful inquiry by demonstrating logical connections and using problem-based learning (Sdunekv \& Waitz, 2017; St. Clair \& Hough, 1992).

A team of four teachers with each teacher specialized in a core subject area has been the most common arrangement (Wallace, 2007). These teachers are expected to work together to broaden learning opportunities for students. Although a teacher may not be trained as an expert in multiple disciplines, they can espouse interdisciplinary beliefs (Drake \& Burns, 2004; Gailey \& Carroll,
1993). In an interdisciplinary team, teachers need to develop teamwork, communication skills, and positive attitudes toward interdisciplinary teaching (Al Salami, Makela, \& de Miranda, 2015), because most teachers feel they lose autonomy while investing time in decisionmaking and potentially have conflicts among each other on the team (Shapiro \& Dempsey, 2008). Teacher choice, curriculum-driven design, and administrative support are necessary for interdisciplinary teams to be effective (Margot \& Kettler, 2019; Murata, 2002).

Several challenges hinder STEM interdisciplinary instruction. First, secondary teachers rarely had experiences in using interdisciplinary STEM instruction in their pre-service teaching experiences. The isolating teaching experience of pre-service teachers sets up barriers to forming interdisciplinary collaboration when they become in-service teachers (Asghar, Ellington, Rice, Johnson, \& Prime, 2012; Frykholm \& Glasson, 2005). Second, teachers feel their content knowledge outside of their disciplinary expertise is insufficient for them to implement interdisciplinary STEM instruction (Baker et al., 2015; Graves et al., 2016). Third, teachers are challenged when aligning what they need to teach with other subjects through the lens of interdisciplinary collaboration (Frykholm \& Glasson, 2005). Fourth, practicing teachers often experience "siloing" of the different disciplines, inflexible class schedules, and stringent timelines for implementing curricula, which can discourage the interdisciplinary nature of integrated STEM lessons (Lesseig et al., 2017). Finally, the lack of a common planning time, such as a professional learning community (PLC), hinders collaborative planning. It is highly recommended that teachers collaboratively discuss interdisciplinary lessons and instruction to make interdisciplinary team teaching work (Capraro \& Jones, 2013; Flowers, Mertens, \& Mulhall, 1999).

The study design was informed by theory. This study addressed the gap of a limited number of high school teachers' operationalizing interdisciplinary STEM instruction (Kelley \& Knowles, 2016). The purpose of the study was to explore high school STEM and agriculture teachers' use of hydroponics as a complex designed system for interdisciplinary collaborations. Supported by literature reviews and empirical research, this study was influenced by existing theory in the areas of how teacher beliefs may have an impact on their practice. The conceptual framework used to design the study was teacher belief scholarship. In addition, analytic induction was used to develop an operational model through empirical investigation that is inclusive of the multiple perspectives voiced by the study participants (Bogdan \& Biklen, 1998). The research questions that guided the study included (1) What were high school teachers' beliefs and practices of interdisciplinary STEM instruction when 
using a complex designed system? and (2) What were the operational interdisciplinary STEM collaboration models when using a complex designed system in high schools?

\section{Methods and procedures}

A qualitative case study research design (Yin, 2009, 2012) was used to structure this study. The study was an instrumental case study (Stake, 1994, 1995) that aimed to better understand teachers' beliefs and instructional practices of STEM integration through interdisciplinary approaches in a complex system. Through categorizing data, we identified patterns and themes and compared them with other cases. The teachers in this study were recruited to participate in a year-long teacher professional development (TPD) program, which aimed to increase their integrated STEM teaching capacity. The participant teachers attended a 1-week immersive training delivered by faculty members and community education specialists in the disciplines of agricultural STEM education, biology, physics, chemistry, and engineering. A hydroponics curriculum was used as an example in the TPD to teach STEM integration through biology, physics, chemistry, and engineering units in a complex agricultural system.

After the TPD, participants formed a collaborative team at their schools to co-develop and implement interdisciplinary STEM lessons and instructions. Although an integrated STEM hydroponics curriculum was provided, participants had freedom to choose whether to use it or develop STEM lesson plans that were most suitable for their classes and school environments. A design challenge of extending the growing season to increase food production was provided as a goal for teachers to structure their interdisciplinary STEM lessons and instructions. The researchers performed follow-up communications with the teachers throughout the year to gain insights about their progress. There were two check-in points, one virtual meeting and one school visit in each semester. During the virtual meeting, held in mid-semester, the teacher participants reported progress regarding curriculum development and implementation, and the challenges they had encountered. At the end of each semester, the researchers visited schools, and met individually with each teacher participant to gain insights about the interdisciplinary collaboration project on which they were working. At the end of the year-long TPD program, each school team shared their progress and lessons at a STEM showcase event. The researchers collected lesson plans at the end of STEM showcase event. The lesson plans were used to triangulate with reflection papers and interview data.

Two cases, which were represented by two teams from two rural high schools in Indiana, were identified for this study. Each team consisted of three teachers. The first school, Lewis high school (pseudonym), was located in a small city in the rural area of Indiana. Since the school utilized an individual classroom approach as its interdisciplinary STEM collaboration, the school will be referred to as the "multi-classroom model." The school enrolled approximately 2200 students from grade 9th to 12th with a student-teacher ratio of 19:1. There were 112 fulltime teachers. The second high school, Stevenson high school (pseudonym), was located in a distant rural area of Indiana. The school used an afterschool club to implement an interdisciplinary STEM education program. Hence the school will be referred to as the "extracurricular activity model." The school enrolled approximately 450 students from grade 7 th to 12 th with a studentteacher ratio of 17:1. There were 27 full-time teachers. Detailed descriptions of each teacher in the two cases are provided in Table 1.

Consistent with qualitative case study design, multiple data sources were used to enhance data credibility (Creswell, Hanson, Plano Clark, \& Morales, 2007; Yin, 2009, 2012). Each teacher completed pre- and posttest questionnaires. Each questionnaire consisted of 11 open-ended questions regarding teachers' beliefs in the pedagogy-knowledge that students preferred, class involvement, and construction of knowledge. Some open-ended question examples were "Do your students learn best in classes that focus on factual information or classes that focus on ideas and concepts? Why do you believe that?"; "What teaching method(s) do you believe has/have the most beneficial effects on your students?"; and "What made the teaching method(s) beneficial? Please be specific and use examples." Each teacher was also asked to respond to four reflection papers that aimed to explore their epistemological and teaching beliefs of STEM integration. The questions for the reflection paper were "What similarities (overlap) do you believe exist among S, T, E, and M?";

Table 1 Teacher participants in the study (*pseudonyms)

\begin{tabular}{lllllll}
\hline School names* and collaboration model & \multicolumn{2}{l}{ Lewis high school multi-classroom } & \multicolumn{2}{l}{ Stevenson high school extracurricular activity } \\
\hline Names * & Josh & Melvin & Ray & Justine & Malcom & Ken \\
Disciplines & Biology & ICP & Agriculture & Biology & Biology & Agriculture \\
Grade levels & HS & HS & HS & HS & Jr. and HS & HS \\
YTE & 8 & 14 & 18 & 17 & 8 & 6
\end{tabular}

YTE years of teaching experience, ICP integrated chemistry and physics, HS high school, Jr. junior high school 
"How do these similarities and differences contribute to frame your perspective of STEM literacy?"; and "From your perspective, which integrated approach is the best model to integrate STEM? Why?"

Toward the end of the year-long program, each teacher participated in a 60-min face-to-face interview. The interview questions focused on acquiring information about teachers' beliefs and experiences in designing and implementing the integrated STEM lessons through interdisciplinary approaches. Example interview questions included "How do you decide what to teach and what not to teach?" and "What factors impact your instructional practices in teaching content knowledge?" Teachers' responses from pre- and posttest questionnaires, reflection papers, lesson plans, meeting notes (if applicable), and notes from all the communications served as data sources to identify teachers' beliefs and instructional practices of STEM integration as well as the definitions and models that they each used to structure STEM integration through interdisciplinary approaches in a complex system.

Data were analyzed by a team of researchers using in vivo and value coding strategies to capture a sense of overall content followed by provisional coding strategy for initial coding (Saldaña, 2016). In vivo coding is "literal coding" (Saldaña, 2016, p. 105) where a researcher labels the key language in the data. For example, Josh described his personal learning style by saying, "I had very little clue about what it actually was. It sounded like something fun to do." Malcom pointed out a successful teaching experience in his classroom by saying, "It's kind of like to have fun getting to memorize those tree species." For these two examples, "fun" was the in vivo code that related to positive learning experience. Value coding "reflects a participant's value, attitudes, and beliefs that represent his or her perspectives" (Saldaña, 2016, p. 131). For example, Ray described how his students solved a problem by saying, "I was surprised by their [students] interest when things weren't working...how they were using some analytical skills they would've never had to use before to solve the problems." Justine talked about how she felt her students helped Malcom figure out the profit of selling flowers in a greenhouse, when she said, "We figured out profit for him [Malcom]. It was something different. I think that helped keep their [students] interest, so that was pretty cool!" For these two examples, "problem solving" was the code that relate to the two teachers' values of using real-world problems in their classrooms. Two researchers independently conducted the first cycle coding by using in vivo and value coding for questionnaires, written reflections, and interview transcripts. After the first cycle coding, 92 total codes emerged. The two researchers debriefed coding and conducted inductive analysis to portray a concept map for individual teachers. During the debriefing meetings, some codes were aggregated into one, and some codes were deleted or replaced by different codes after discussions. At the end, between 24 to 47 initial codes were used to create six teacher's concept maps. Regarding disagreement, the two researchers engaged in peer debriefing until consensus was reached for discrepancies of codes and concepts. To ensure the trustworthiness of the qualitative analysis, during the debriefing meetings, the two researchers also conducted intercoder reliability for both in vivo and value coding. After several debriefing meetings, the final intercoder reliability for in vivo code was $97 \%$ and value code was $93 \%$. In addition, the two researchers also examined internal and external supporting and hindrance factors that emerged from the data sources by using Buehl and Beck's (2014) model. The two researchers used the framework to categorize the internal and external factors that supported and hindered participants' beliefs and their instructional practices of STEM integration through interdisciplinary approaches in a complex system.

After the first cycle of coding and debriefing sessions, a concept map for each teacher of his or her beliefs and practices for interdisciplinary STEM instruction in a complex system emerged. Then, the two researchers conducted a second coding session by using the individual concept maps to generate central concepts, where categories were triangulated against lesson plans and notes from teachers. For example, in Malcom's individual concept map, three codes (i.e., learning from different teachers, hands-on activities, and applying knowledge) were associated with the central concept of integrated STEM teaching. In addition, the code learning from different teachers also related to the central concept of interdisciplinary collaboration. As for triangulation, for example, Melvin created five lesson plans. All of his lesson plans used hydroponics as a lab, where his students conducted various scientific experiments, such as determining the temperature needed to grow basils in a hydroponic system. His lesson plans aligned with one of his central beliefs of integrated STEM teaching, which was to understand how scientists' approaches could solve the world's problems. Finally, the two researchers conducted within cross-case analysis by comparing and contrasting the qualitative data to identify themes from individual teacher's concept maps (Saldaña, 2016). For example, extracurricular activity model had three themes: need to address standards, need to have different teachers, and need to help students make STEM connections, which emerged based on the cross-case analysis. Trustworthiness and credibility were supported using several strategies including multiple data sources, prolonged engagement, and triangulation (Shenton, 2004).

\section{Findings}

In this section, individual participants' stories focusing on their beliefs and practices in each school are 
described. The purpose of providing individual's stories was to support the within cross-case analysis presented in the discussion. Each story portrayed individual teacher's (1) lessons, (2) teaching beliefs, (3) instructions, and (4) ideas of interdisciplinary collaboration and challenges. In addition, an interdisciplinary collaboration model is presented for each school.

\section{Case 1: multi-classroom model (Lewis High School) Josh (Biology)}

Josh's lessons utilized a hydroponics system to focus on the flow energy among organisms in an ecosystem. His lessons included an algal bloom lab, photosynthesis, and designing an experiment and collecting data. He worked with Melvin, the integrated chemistry and physics teacher, to co-develop the Shark Tank lesson, where students developed a sales pitch on their experimental design and presented to the class. A big portion of his lessons used mathematical modeling to explain the ecosystem. Both the algal bloom and photosynthesis and the data collection lessons represented "question, research, and design/test" stages of the engineering design process. His students set up an experiment and collected data on how fast plants or seeds could grow in an environment where different lighting systems were used. Students also re-designed their experiment based on the data they collected to help plants grow faster. The Shark Tank lesson provided the opportunity for students to share their results. Students used their experiments from previous lessons to pitch a new design or the best design that could grow plants the fastest.

Josh liked to learn and try new ideas. He explained the reason why he participated in the interdisciplinary team. He said, "For eight years, I've been teaching the exact same course and with the exact same books...So, it's just something new." He was looking for a new approach to teach biology to his students. He considered his teaching not to be standards-driven. He still covered the standards, but in a more meaningful way, not just by using textbooks. Josh would like to use more discovery learning techniques, but he also believed there were times when he had to lecture (e.g., using textbooks and explaining the science content). He said, "I think what works best in practice is a little bit of everything...where you have to lecture because they [students] are not going to be able to get it." For example, some topics, such as cell parts, were better suited for lecturing in his class. Josh tried to make real-world connections, which was what he referred to as "teaching content in a more meaningful way" to his students. For example, he tried to humanize science by showing students a portrait of Mendel when he taught the Law of Segregation, the Law of Independent Assortment, and the Law of Dominance. He emphasized the importance of the real-world connections by saying, "I think it's being able to make the connections between the new content and being able to apply it outside of scenario that it was presented to you...If you can do that, then you truly understand the idea and you've learned it."

Josh considered STEM integration as a long-term project. He believed hydroponics would provide the contextual framework to teach biology. As such, Josh shared that he connected learning standards and lesson objectives to the context. Josh wanted his students to act as real scientists by growing the plants, recording and analyzing data, changing a variable, and then repeating the experiment again. He said, "So, that's where getting them [students] involved in. I said to them [students] 'All right, so we grow the plants. We record the data and figure out everything. Well, now change a variable. Do it again.' This is what real scientists do for their job." Josh had a routine when he taught his class. First, he engaged students by setting up experiments including a hydroponics lab. Then, he introduced content to his students. He stated that he often lectured this part of his lessons. After introducing the content, he engaged students in guided inquiry by facilitating student learning via experiments that he had set up. Students followed his instruction to conduct experiments, such as collecting and analyzing data to answer the questions that he asked them. After that, he gave students the freedom to modify the experiments or to design their own experiments.

As for interdisciplinary collaboration, Josh believed the team would be better with more teachers from different disciplines. For example, when his students transitioned to Melvin's class the following year, students would use the same context (i.e., hydroponics) to learn science content in a different classroom. In one of his reflections, he described how he pictured interdisciplinary collaboration. He wrote, "[For interdisciplinary collaboration,] not only do we [Melvin, Ray, and Josh] hit all the different disciplines, but we are doing so with different levels of students...My students will be in Melvin's class next year, and they already have the basic biology knowledge of how this works." In his interview, Josh said, "So, I can really see it being a..., almost like a multiyear project where we get to use this set up [hydroponics] to hit all these different classes...We're growing crops. It is not just agriculture, and biology. It's also physics and chemistry...It is everything." He stated that, in this way, students could connect what they had learned in his class with other disciplinaries, such as chemistry and physics. When students see connections among the content areas, they could better understand and retain the knowledge. Josh also talked about some challenges regarding interdisciplinary collaboration. He suggested that in his regular biology class, he needed to align his teaching with the other biology teachers. Therefore, it was hard 
for him to incorporate integrated STEM. However, he was the only teacher who taught AP biology, so he could be flexible with what he chose to teach. Josh also would like to have more planning time with other teachers, because each teacher had different viewpoints, strengths, and weaknesses. He said, in Lewis high school, teachers did not have a common planning time, making it difficult to collaborate with other teachers. In addition, he mentioned that administrators' support was also important. In one of the meeting notes, he wrote, "We flooded the greenhouse. People wondered what we are up to, but our department head was cool about it."

\section{Melvin (Integrated chemistry and physics)}

Melvin's lessons focused on collecting and using data from various labs (e.g., light vs. height, $\mathrm{pH}$, seed planting and germination, and power vs. water pump). In all labs, his students graphed and interpreted data to identify the relationship between the data and the variables. He had certain procedures that students were expected to follow. For example, in the temperature lab, he wrote that students needed to maintain a constant temperature for the plants and then recorded plant growth each day for a week. Students repeated the process with a different temperature and recorded plant growth for several weeks. Students used the analyzed data to determine the best height for an indoor light that would enable plants to grow the fastest. He designed the Shark Tank lesson with Josh, the biology teacher. The Shark Tank lesson was a communication channel for students to present their findings in his class.

Melvin liked to build things. He described what dragged him into the project by saying, "I like playing with the things that I build. So it's [the hydroponics] just an adult version of Legos...I wouldn't have been able to keep myself away." He wanted his students to play while they were learning. In one of his open-ended questionnaires, he wrote, "I would rather run a class where they [students] can talk and have fun AND learn efficiently." Melvin said if he did not know what to do for teaching, he started with labs. He said, "When you don't know exactly what you're asking them [students] to do, it's a good way to start labs, and then later, you might find this is the most fun and informative way of teaching." In addition, he also learned from students' lab experiences. He could adapt and reuse them to set up different labs for other courses. After the TPD program, Melvin had some general ideas for incorporating hydroponics into his teaching. Yet, he really did not know what he wanted to do. Therefore, he experimented with hydroponics and decided to set up different labs using hydroponics as a context. He stated that it was hard to teach something he had not used before. Everything he learned from his experience this year would be a lab next year. $\mathrm{He}$ explained, "Once I watched the students tried things a few different ways, then I started to see if there should be a lab next year. A couple of the labs that I wrote were purpose-driven. For example, I wanted them [students] to tell me how high it [water pump] can pump the water. It was for me, originally."

Melvin believed that the best teacher was someone who could effectively use different teaching strategies. From his perspective, a successful teacher was somebody who was trying a little bit of everything. He wrote in his reflection paper, "The thing that makes a teaching style effective, it matches the students in a class. If there are different types of students, and there almost always will be, it is best to switch styles often." Like Josh, Melvin had a routine when he taught. Melvin's teaching style utilized lecturing and discussion. He started with lecturing on the content area (i.e., knowledge of physics). Then, he had students discuss the content and write assignments. After he was confident students had a good understanding of the content, he set up hands-on activities for students to do, such as labs. Then, he had students discuss the lab experience. Although content knowledge was the goal of his teaching, Melvin said he wanted something his students could measure, which was a very important part of his class. He also mentioned that the more students saw real-world problems being solved, the better. He said, "I try to get them [students] to bring real problems to the discussion, or physically bring things in, so we can figure out how to solve those. Otherwise, they [students] just think that science is only for scientists." He wanted students to see science as a tool they could use to solve problems. The hydroponics experience made him much more interested in open inquiry methods, because he was also learning the process and dealing with things with which he was not familiar. He understood this was how real-world scientists do things, but he needed to digest his experiences and transfer the experiences into his teaching. He stated, "I didn't know how it [hydroponics] would work until I played with it. I was just trying everything and now I've got a list in my head to tell students 'oh, I've done that.' So, I think I was doing science for my teaching."

Melvin believed that interdisciplinary collaboration happened when everyone focused on his or her roles. For example, he liked to build. Therefore, he helped build the hydroponics growing chambers, while the rest of the team, Josh and Ray, added biology and agriculture content. Melvin believed an interdisciplinary team should have three to five teachers from different subject areas. Melvin suggested that although competition was a critical component that needed to be included in the hydroponics lessons, his idea of competition was slightly different from Josh's. He said, "He [Josh] loves competition. So, that [Shark Tank style] was sort of his idea. I 
may do it more like..., in my class, that [competition] might look like who can get the water to pump the highest." Melvin agreed that his idea was similar to Josh's idea, but they did not have time to plan the lesson in detail.

\section{Ray (Agriculture)}

Ray did not have specific lessons developed for a hydroponics system. He had a complete aquaponics project that was already built in his lab and used it to teach the concept of production to his students. Therefore, he continued to use the aquaponics project as his STEM project. Students grew lettuce and raised tilapia fish using the aquaponics system. However, no lesson plans were developed to document his teaching of integrated STEM using aquaponics.

Ray said he often used the same lesson plans every year. The STEM project (i.e., hydroponics) gave him new things to add to his teaching. The reason that he participated in the project was "to give my students new experiences, and also keep myself on the cutting edge of new things." He believed it would be fun to work with some of his colleagues. Ray followed the National Future Farmers of America Organization (FFA) motto "learning to do, doing to learn, earning to live, and living to serve" to teach his class. Ray explained that he learned best when he did hands-on learning. He also wrote "The most effective teaching method is hands-on experience" in the open-ended question of a questionnaire. Therefore, he believed that his students also learned best by doing hands-on activities. He gave an example of how he and his students learned about the impact of the nitrogen level on the growth of tilapia using the aquaponics system. He explained that, at first, his students followed the instruction on a bag of fish food to feed the fish. The fish were not starving, but the lettuce did not grow as fast as they expected. To increase the nitrogen level, his students doubled the amount of fish food by feeding them twice a day and they obtained the result they wanted. Ray focused on providing students with experiences. He and his students did not measure the nitrogen level to determine how much food they should give to the fish to optimize nitrogen production or to have the best biomass at the end of the project. He admitted that he was not as scientific as he should have been with his class by saying, "We [students and I] should've been measuring stuff more, I think. And that's what I would change for the next time. We should've measured the actual distance that worked the best. We should've calculated the weight of the biomass at the very end." In his reflection paper, he wrote, "I like to know what we started with, what we ended with, and why does it. For example, we started with a trace amount of seeds, we measured biomass, and I asked questions like 'where did it come from? The light and the water?"

Ray usually taught vocabulary first. After students had a basic foundation of definitions, he gave students some hands-on resources and had them solve problems. Because Ray was not required to follow standardized test preparation, he had more flexibility in making instructional choices compared to Josh and Melvin. He believed engaging students by using real-world examples was crucial. He said, "We figured out it [lettuce] wasn't getting enough nitrogen. We weren't feeding the fish enough. So, we started feeding them [the fish] more and we started getting the nitrogen level to where it needed to be. When you do a project like this, students remembered it forever." Therefore, he encouraged students to apply what they learned from his class to their daily life, such as composting at home. He wanted to prepare his students by doing things that real farmers would do, such as harvesting pumpkins and growing corn. He localized his teaching to connect students' everyday lives with local agricultural businesses. He wanted to teach the content that was practical, which students could use or apply in their everyday lives. He explained, "Well, that's what we [teachers] are supposed to be doing...prepare them [students] for life after high school, right?"

Ray believed that the interdisciplinary approach allowed teachers to use their strengths to teach a more complex idea to students. He felt his class could help integrate other subject areas. He believed that his contribution to the interdisciplinary collaboration was to provide real-world examples to help students see the connections and apply what they had learned to a reallife situation. Ray was amazed to see Josh and Melvin using analytical skills to solve problems with their hydroponics systems. He stated that it was fun to watch Josh and Melvin became really engaged with hydroponics and asked their students to conduct experiments. He said that Josh and Melvin visited him and asked him questions regarding plants, but reciprocally, he did not reach out to them regarding scientific content he could integrate in his class. He stated, "I should've used them [Josh and Melvin] more...but they would come down and ask me: 'Our system is leaking, what should we do?' and 'Is this [a basil] getting enough water? What do you think?"' $\mathrm{He}$ suggested interdisciplinary collaboration could become more successful if they had common meeting times to discuss about how they could work together. He said, "At least five to ten times where I talked to them [Josh and Melvin], I would say there was definitely some collaboration. There could be more, but we did not have a time where we all meet."

In multi-classroom model, we described themes that were related to features, beliefs and practices, and challenges of interdisciplinary collaboration. 


\section{Features of interdisciplinary collaboration}

Multi-classroom model occurred in different classrooms. There were three distinguished features in multiclassroom model. These three features were (1) a team of three to five teachers from different subjects; (2) each individual teacher took on his or her role in the collaboration; and (3) a real-world problem or challenge that related to students' everyday life was the glue holding the interdisciplinary team together (Fig. 1). The teachers, who used multi-classroom model, admitted that they only achieved a rudimentary level of their ideal interdisciplinary collaboration.

\section{Beliefs and practices of interdisciplinary collaboration}

Lewis high school teachers, who used multi-classroom model, felt they needed some changes and innovative educational resources to teach their students. They believed that the state standards were only guidelines. They could use different activities and teaching strategies to help students learn content to address the standards. They believed that through the interdisciplinary STEM collaboration, they could learn from each other. The teachers acknowledged that different teaching strategies were used in science and agriculture classes. The teachers believed teaching content knowledge was the first step of instruction. The science teachers used hydroponics to teach scientific inquiry process. The agriculture teacher focused more on technical aspects but less on the scientific concepts of hydroponics. The science teachers were inclined to use structured inquiry (Colburn, 2000). They felt that they needed to internalize the knowledge and conduct experiments before they could fully grasp STEM integration using hydroponics to teach their students. As for the agriculture teacher, his approach was mainly doing hands-on learning. Although his approach had a potential to be considered as guided or open inquiry (Colburn, 2000), he was not as scientific as his colleagues.

\section{Challenges of interdisciplinary collaboration}

The teachers mentioned one of the biggest challenges was they did not have a common meeting time for the interdisciplinary team to meet. This hindered their collaboration, because they could not get together to discuss their curriculum and to identify ways to collaborate. In addition, although teachers did what they could to teach their students in different classrooms using hydroponics, they believed a venue, such as an afterschool hydroponics club, could benefit students more from their interdisciplinary STEM teaching. After the teachers taught the content in different classrooms, students from different classes could utilize the venue and work on a common project, such as hydroponics, by applying parts of the knowledge that they gained from different classrooms to solve real-world problems.

\section{Case 2: extracurricular activity model (Stevenson High School)}

The team of teachers at Stevenson high school organized an afterschool program focused on hydroponics. The teachers modified instructions from a hydroponics

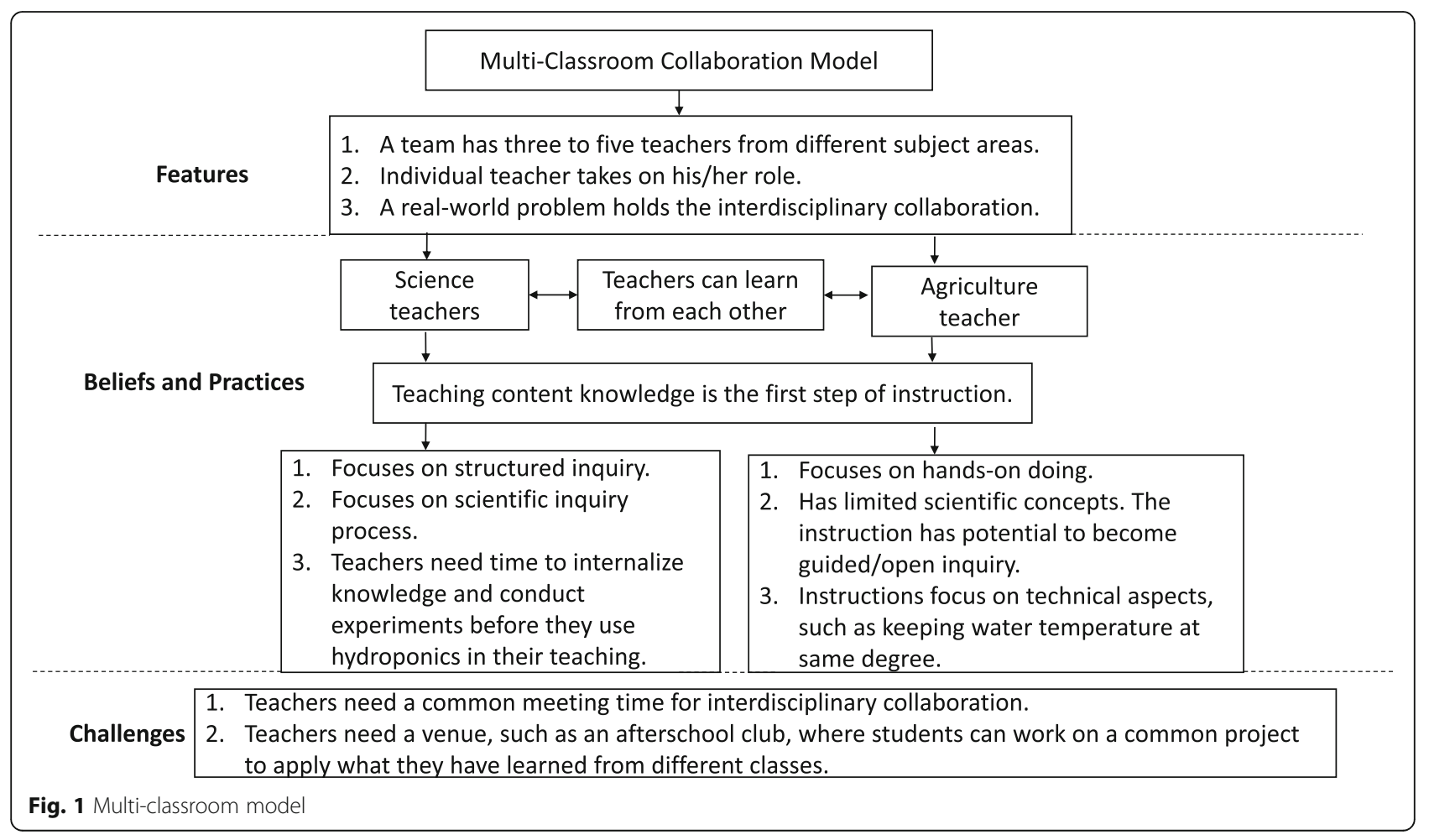


textbook that was provided by Ken, the agriculture teacher, and used it throughout the year. The main reason that the team decided to organize the afterschool program was because the teachers did not share students in the same semester. The afterschool program aimed to provide real-life examples and hands-on applications to support what students learned in their regular STEM classes. The lesson plans focused on designing, constructing, and maintaining a hydroponics system. The team of teachers identified several academic standards in agriculture, mathematics, and biology they planned to teach. However, there were a small number of students participating in the afterschool program and the teachers were unable to teach all planned lessons. A major portion of the program was used for students to research information about hydroponics systems using inquirybased learning. Students compared and contrasted pros and cons of the hydroponics designs before they decided on what type of hydroponics system to construct. In addition, the team spent time teaching students how to use tools, such as electric drills. Ultimately, teachers and students worked together to construct and maintain the hydroponics system.

\section{Justine (Biology)}

Justine's teaching goal was for students to learn about something in life and have the ability to solve problems. She believed that students should apply content knowledge rather than just memorizing it. In her interview, Justine said, "My big goal...I always want them [students] to be able to understand it [STEM knowledge] and apply it. Like it's one thing to know a definition but, okay, take that definition and give me an example of something that fits into that category." Justine believed that the teacher's role was a facilitator. Teachers should provide basic content knowledge and a platform for students to express ideas and find solutions.

Justine believed that using hands-on experiences helped students make connections to what they had been learning in class. She noted that teaching through hands-on experiences had been the best strategy because students liked them. She stated, "The majority of them [students] like to do hands-on stuff, which makes sense because students don't want to sit down the whole time. So hands-on, I think, is probably the best." Justine believed that the integrated STEM project had the potential to offer those aspects to her students. This reason, coupled with her experiences with interdisciplinary projects at her previous school, led her to become part of the STEM team. In Stevenson high school, she faced the challenge of insufficient time to implement the afterschool program or interdisciplinary project in her own class. She wrote in one of her reflections, "Time is the biggest factor, the constraint, to teach it [hydroponics], and have students worked on it."
In Justine's teaching, apart from the textbooks, she had been using real-world and everyday examples because they provided more relatable learning experience to students. Her strategies for inquiry-based learning included providing some basic knowledge, giving a few directions, and letting students come up with solutions. However, she felt obligated to teach her students the content needed for the state and national tests and to teach her class strictly based on the standards. "Statewide Testing for Educational Progress takes the fun out of what we do as teachers," she said. Justine's goal of teaching STEM was to familiarize students with using different disciplines in exploring the same topic. Moreover, she added that students should be taught that there is more than one solution to a problem. However, having to follow the standards prevented Justine from integrating STEM in her biology classes. In addition, Justine considered STEM integration as collaboration with other teachers in the same semester. Therefore, not sharing students became an obstacle in implementing the STEM integration project. She said, "I think it's a lot more difficult at a small high school. I could see it working at a big high school where you have teams and you share students, but it's difficult here when we don't share students." She believed that although she used some aspects of integrated approaches in her biology classes, based on the TPD program, she learned that was not how STEM integration was intended to be used.

For interdisciplinary collaboration, Justine addressed that the team members did not have the same planning period. Using email was the common form of communication between the team members, but that was not an ideal solution. Moreover, Justine did not see or understand her role in the project. She thought that students should have already learned about plant growth through living in an agricultural community, and therefore did not need her to explain the biology aspect in a hydroponics system.

\section{Malcom (Biology)}

Malcom believed that STEM collaboration meant having students from one class learn from different teachers. He believed a teacher should be responsible for their own portion of teaching the content from their academic discipline. Malcom saw the importance of STEM integration in an educational setting. Especially, STEM engaged students' learning by using hands-on experiences. As Malcom highly valued practical application, he wanted students to be able to apply the content knowledge in everyday life. He said, "I think that [STEM integration] has the practical application of the engineering and the technology. To be able to apply that in the classroom with our science, our biology, I think that is very important for students nowadays." Additionally, he 
wanted his students to possess problem-solving skills. Despite the values Malcom perceived of STEM integration, he was required to use the standards and teach according to the state exams. This prevented him from using hands-on experiences in teaching STEM because he did not think they fit together. Malcom's style of teaching was the mixture of textbooks and practical application in the labs. Specifically, he promoted the use of senses (i.e., sight, smell, hearing, taste, and touch) for students to better understand the content. $\mathrm{He}$ also used guided inquiry by directing or motivating students to find answers on their own.

Malcom did not express his full support for the afterschool program for multiple reasons. First, he did not feel that the afterschool program was his direct responsibility. This was because the students who attended the program were not from his class. Second, he viewed that STEM integration should be done in a regular course throughout the school year. He said, "For us to do this correctly in my opinion, we would need a set time frame so that I have a class, like first hour, every day. We can call it biology STEM, whatever it may be. It needs to be run as a class." Third, although Malcom saw the potential of teaching biology using the hydroponics system, he believed the topic was too complicated and too advanced for students at the freshman level and lower, which was the majority of his students. He explained, "It's [hydroponics] not in the standards to do. Now, some of it, a couple of little things are. Obviously, the mathematics is there. I think it would fit perfectly in my high school curriculum, but I only had one section of the high school freshman biology." To address these concerns, Malcom discussed some ideas for the future. Malcom planned to switch classes with Ken for a few periods in order to fulfill the inclusion of different teachers from different disciplines teaching the same class.

\section{Ken (Agriculture)}

Ken believed that STEM and agriculture, food, and natural resources (AFNR) disciplines were all mixed together rather than separated. STEM and AFNR disciplines offered another set of skills to students, which motivated Ken to participate in this STEM project in the first place. Ken was interested in having teachers working together to provide hands-on experiences. He said teacher collaboration allowed students to see the importance of the activity while offering a more enjoyable experience. Ken saw hands-on experiences as a way to reinforce the content knowledge and the standards. $\mathrm{He}$ said, "I start off with a lecture to give students base knowledge. Over the course we add more advanced materials and then I always like to follow up with a handson activity or lab. I feel they [students] learn the best that way, when they're actually able to apply it [knowledge]." Therefore, he emphasized hands-on activities in his teaching.

Ken believed that the role of teachers was passing on knowledge to their students. His vision of a successful agriculture teacher was a teacher who used academic standards combined with the three-circle model of Agricultural Education. His instructional practice aligned with the model by structuring his class to align with various FFA contests. His class structure consisted of $60 \%$ lecture, $20 \%$ lab, and 20\% test. When asked to describe his teaching strategies, Ken wrote "factual information that is accompanied by hands-on learning" in one of the open-ended questionnaires. He indicated that "factual information" was the state standards that he needed to teach by stating, "The content knowledge is the state standards. The state standards don't really give me much of a choice." He also believed in re-teaching to ensure that the majority of the students were ready to move on to the next topic. In general, Ken instructed students to re-design the experiment's instructions from the book into processes that they understood. His idea of guided inquiry was acquiring students' inputs, letting students see "something that matters," and thinking about how to solve the problem.

Ken believed that teachers from different disciplines must collaborate and use learning standards in the collaborative teaching. The collaboration must happen throughout the school year. He stated that the collaboration enabled teachers to identify students' problems, provide the help they needed, and ensure all students got the help they needed. This belief led him to feel that the team faced challenges by having too many teachers. Too many team members resulted in scheduling problems to meet, which negatively impacted collaboration among the teachers. He said, "We only had four teachers. We [the team] did not have time to meet in a structured meeting, but we send emails to each other. It did not feel like we were all there at the same exact time, but somehow I felt that we were still collaborating." Ken assumed that an afterschool program would allow more time to spend with students, but in reality, the students were already engaged with other activities and were unable to fully participate in the program.

In the extracurricular activity model, we described themes that were related to features, beliefs and practices, and challenges of interdisciplinary collaboration.

\section{Features of interdisciplinary collaboration}

Extracurricular activity model occurred in an afterschool program. Three distinguished features were found in the model: (1) need to address standards; (2) need to have teachers in different disciplines; and (3) need to help students make STEM connections (Fig. 2). Stevenson high school teachers, who used extracurricular activity model, 


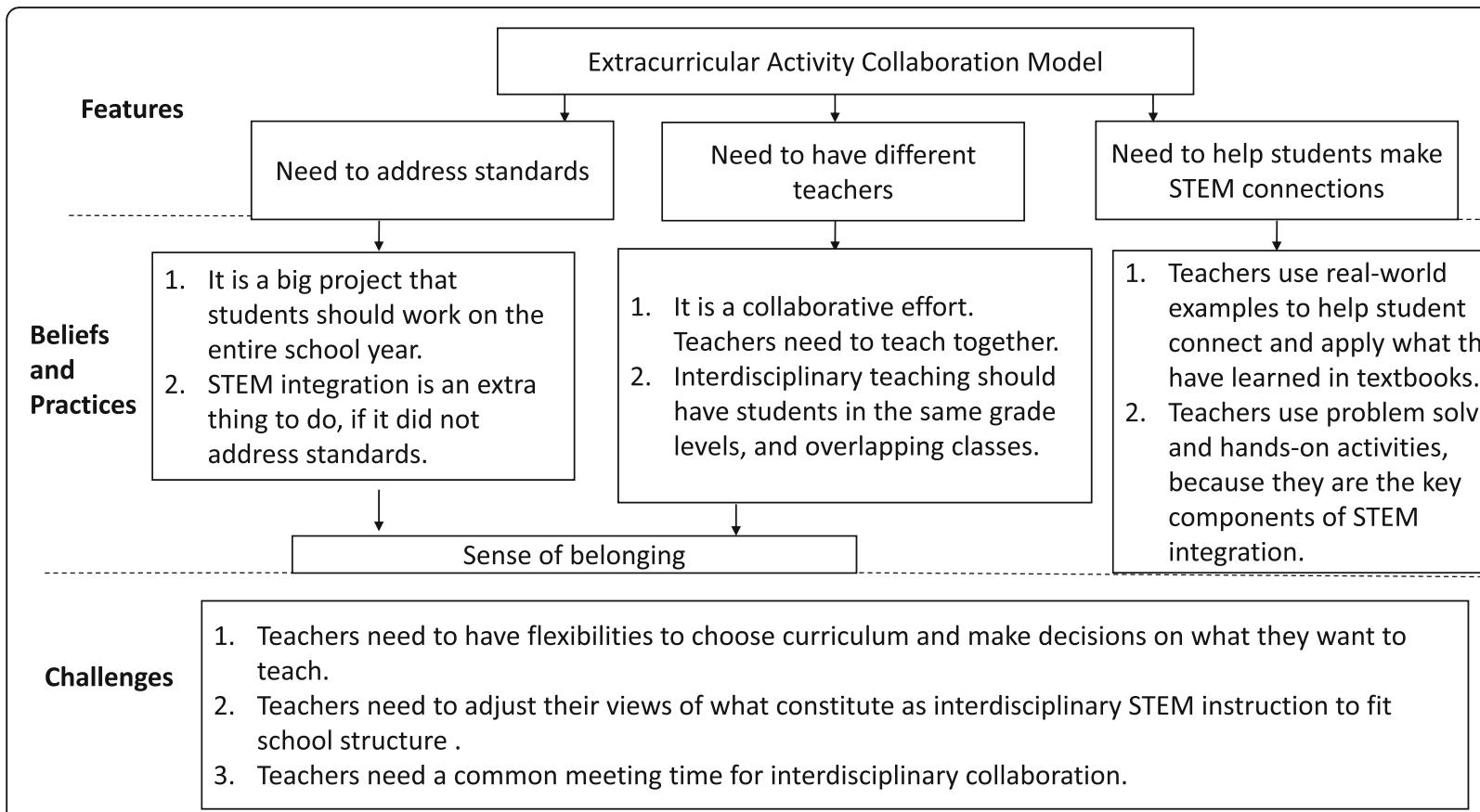

Fig. 2 Extracurricular activity model

admitted that interdisciplinary collaboration did not happen, although they tried.

\section{Beliefs and practices of interdisciplinary collaboration}

Stevenson high school teachers, who used extracurricular activity model, believed interdisciplinary STEM collaboration meant doing a big project that students could work on through an entire school year. Therefore, they chose to implement their interdisciplinary hydroponics project in an afterschool program. Some teachers felt they had limited control over the students who participated in the afterschool program. Because the teachers needed to teach the required curriculum, teaching STEM integration using a complex designed system was extra work for them. Although the teachers could see the potential of the hydroponics project, it was not in the state standards they were expected to teach. In addition, it required additional work for students to work on it as well. Therefore, although interdisciplinary STEM integration likely addressed cross-curriculum standards, the project did not work for the teachers because it did not align with their content standards.

The teachers believed that interdisciplinary collaboration needed to be done in the same classroom or have the same students in their classes and students needed to be at the same grade levels. If interdisciplinary STEM integration happened in different STEM classrooms and different grade levels, it was not their vision of interdisciplinary collaboration, which raised an issue of sense of belonging. Although an afterschool program could provide more time for students to work on a long-term project, the teachers felt that it did not contribute to interdisciplinary collaboration because the students who participated in the program were not their students. Some teachers felt that they were not needed in the interdisciplinary collaboration project because they were not the hydroponics experts and the project did not specifically address the content standards they taught.

Stevenson high school teachers wanted to use the interdisciplinary STEM project to help students make real-world STEM connections. The teachers felt their job was to provide learning opportunities that used textbooks to address state standardized tests, engage students in conducting research and brainstorming ideas, and collect and interpret data to solve problems. They valued the practical application and believed the hydroponics project was a real-world example that students could use to apply knowledge from textbooks to solve problems.

\section{Challenges of interdisciplinary collaboration}

The teachers resorted to an afterschool program because of several challenges: (1) working with a mandated curriculum that centered on state standards and tests; (2) their view of what constituted interdisciplinary STEM instruction, such as students needed to be in the same grade levels; and (3) the teachers did not have a common meeting time for the interdisciplinary team to meet which limited collaboration.

\section{Conclusions}

Based on teachers' beliefs and their interdisciplinary STEM collaboration practices, three components were 
identified. Team size, teaching goal, and collaboration structure highly affect a successful interdisciplinary STEM collaboration model in high school settings.

Defining team size, both multi-classroom and extracurricular activity interdisciplinary STEM collaboration models had three (ideally up to five) teachers from different subject areas, which was also what the literature recommended (Wallace, 2007). Teachers believed as the team gets bigger, it was harder to manage in terms of coordinating meeting time. Therefore, in the context of interdisciplinary collaboration, team size is a new factor and a common PLC time could be added to Buehl and Beck's (2014) model as one of the external supports and hindrances.

As for the definition of the teaching goal, both schools had the same goal for integrated STEM instruction by using a complex designed system. The goal, aligned with the teachers' internal beliefs (i.e., experience and knowledge; Buehl \& Beck, 2014), was to use real-world problems to help students see STEM connections, learn STEM knowledge and skills, and apply STEM knowledge and skills to solve real-world problems. The integrated STEM lessons always started with their students learning the content. Although all teachers expressed a similar goal to implement integrated STEM by using a complex system, the science teachers and agriculture teachers used different teaching approaches, which were informed by their pedagogical beliefs (Pajares, 1992; Weinberg \& McMeeking, 2017). The science teachers tended to focus their teaching on scientific processes, such as experimental design, data collection, and data analyses. The agriculture teachers tended to focus on content application and technical aspects of the complex system. Teachers held beliefs about domain specificity knowledge (Buehl \& Alexander, 2001, 2006; Hofer, 2000). Our results showed the teachers' domain-specific knowledge was aligned with their teaching practices. This finding added another layer of challenges for interdisciplinary collaboration. To mitigate this challenge, we believed science teachers and agriculture teachers could find common ground to solve the dissimilar teaching approaches and be complementary to each other because hands-on experiential learning and inquiry-based learning were one of several forms of constructivism (Parr \& Edwards, 2004).

For the definition of the collaboration structure, one of the biggest differences between the two cases was that in Lewis high school, which is multi-classroom model, each teacher took on their role (e.g., taught content knowledge) in different classes. On the contrary, Stevenson high school teachers felt in order to do interdisciplinary collaboration, all teaching needed to be in the same class. Multi-classroom model was inclined to work with the current school system. Whereas Stevenson high school's teachers established more restrictions for what they pictured interdisciplinary collaboration should look like. Therefore, they implement the extracurricular activity model. In other words, in the context of interdisciplinary collaboration, how teachers weighed external factors with their beliefs (Buehl \& Beck, 2014), such as state standards, testing, school system and culture, and time, have influenced their operational interdisciplinary STEM collaboration model and practices. Although both high schools were accountable to teaching the same state standards and their students being evaluated by the same state test, Lewis high school navigated their collaboration differently than Stevenson high school. Teachers at Lewis high school shared they were supported by their science department head and were able to work together in implementing different designs of a complex system. Their collaborative approach was also beneficial to students because the students were able to see different designs of a complex system. In contrast, teachers at Stevenson high school planned to collaborate during the TPD; however, they shared that the principal wanted them to focus on a structured approach to teaching the state standards to prepare students to perform well on the state standardized test. Teachers at Stevenson high school shared they were not as effective in navigating this challenge because their PLC time for STEM integration was replaced with the principal's priorities. This difference in how teachers collaborated was influenced by external factors (i.e., school culture and community; Buehl \& Beck, 2014).

Both multi-classroom and extracurricular activity models considered afterschool programming as a place where students could apply what they had learned to design a complex system and solve problems. Although an afterschool program was considered a critical component for implementing interdisciplinary STEM instruction by using a complex designed system, a few factors should be taken into consideration when using an afterschool program as a venue for students to apply their STEM knowledge and skills. Learning from Stevenson high school's experience, the teachers needed to feel they could contribute to the project. Even in an afterschool program, the teachers encountered challenges to align what they needed to teach with other subjects through the lens of interdisciplinary collaboration, which had been identified as a critical challenge (Frykholm \& Glasson, 2005; Weinberg \& McMeeking, 2017). To sum up, if teachers did not feel the content knowledge that they taught was aligned with the integrated STEM project and students could not apply what they learned to solve problems; they lost interest in participating in interdisciplinary collaboration. Similarly, Knobloch (2008) found that elementary teachers were more likely to integrate AFNR into their classes if they saw AFNR topics and 
activities could be integrated into academic content areas and integration would be educationally beneficial for students.

Teacher beliefs played an important role in how teachers interpreted what they believed STEM integration should look like and how to implement it. In the two cases, it appears that all the teacher participants believed STEM integration could bring in more opportunities for authentic learning through inquiry-based or project-based hands-on activities. They also valued interdisciplinary collaboration, and believed their subject area could play an important role in an interdisciplinary team. However, their operational interdisciplinary STEM collaboration model was influenced by external factors (Buehl \& Beck, 2014; Pang \& Good, 2000). Although all teachers in this study believed interdisciplinary STEM education should help students apply STEM knowledge (content knowledge) and skills to solve real-world problems, their practices of interdisciplinary collaboration resulted in how they weighed external factors, especially standardized testing and administrative support.

\section{Discussion}

Based on the two operational interdisciplinary STEM collaboration models, the study also expanded the concept of a continuum of STEM approaches to curriculum integration, disciplinary, multidisciplinary, interdisciplinary, and transdisciplinary (Vasquez, Sneider, \& Comer, 2013), and providing frameworks for structuring a successful interdisciplinary collaboration model in high school settings (Fig. 3).

In the single discipline model, which signifies the extracurricular activity model, a lead teacher invites other teachers to help deliver an afterschool interdisciplinary STEM project that uses a complex system in their classroom. Other teachers do not have any of their students involved, and may not feel they have any ownership in helping with the project. The afterschool project is taught by the lead teacher from one disciplinary perspective. This model does not work as an interdisciplinary model because the other teachers are not invested in the project.

In the multidisciplinary model, which indicates multiclassroom model, the integrated STEM project that uses a complex system is considered as a common laboratory experience that is embedded within different disciplinary teachers' individual classrooms. Teachers did not have any shared planning time during the school day (i.e., PLC). However, teachers used the common laboratory experience to apply the content they taught to their students. Students were able to observe the projects built by students in the other classes, even different grade levels. This model may create informal conversations outside of the classrooms among students and teachers in the other classes, and help the teachers and students see how a common laboratory experience could result in different STEM projects. Although this model has potential for greater collaboration among the teachers and their students, this model is not considered to be interdisciplinary learning.

The authors created the interdisciplinary model based on the teachers' and their students' experiences from the two different cases. The teachers in this study recommended that an afterschool program consisting of teachers and students from each discipline (a.k.a. classrooms) have a shared common laboratory experience in an afterschool program by growing plants hydroponically based on the contributions of each discipline. This model encourages authentic interdisciplinary learning and uses knowledge, skills, and perspectives that blend different disciplines to solve problems and design a complex system. This approach of having all teachers and students from different disciplines working together on an integrated STEM complex system project is important because they would share ownership of the afterschool program. However, this model could be challenging for teachers and students who have other afterschool commitments (e.g., sports, fine arts, jobs).

\section{Limitation and future study}

Our findings echo what literature had identified as hindrances for interdisciplinary collaboration. Inflexible class schedules, mandated curriculum and standardized tests (Lesseig et al., 2017; Murata, 2002), unsupportive administrators (Murata, 2002), and lack of common meeting time to collaboratively discuss interdisciplinary lessons and instructions

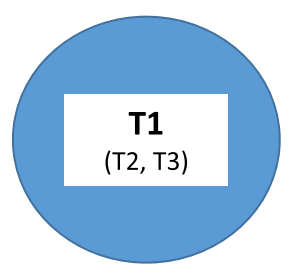

Single Disciplinary

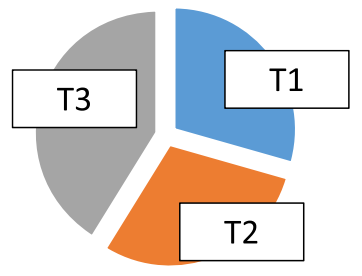

Multidisciplinary

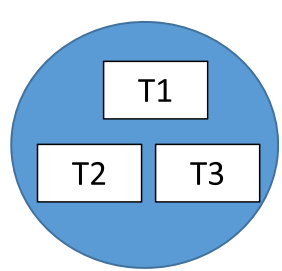

Interdisciplinary

Fig. 3 High school teachers' interdisciplinary STEM collaboration models by using a complex system. The circle represents how teachers use a complex system. The rectangle represents teachers from different disciplinary backgrounds 
(Capraro \& Jones, 2013; Flowers et al., 1999) limited the success of interdisciplinary collaboration. Although all participants acquired their administrator's approval to participate in this project, the various challenges, inflexible class schedules, mandated curriculum and standardized tests, unsupportive administrators, and lack of common meeting time to collaborate were administrative related. Because this study was designed to focus on teachers' beliefs and practices, data from the school administration were not collected. Therefore, lacking the administrators' perspective, the interdisciplinary collaboration models from both schools are missing an important piece. As such, the authors recommend future studies investigate contextual and organizational barriers and affordances from the administrators' perspective to identify ways STEM integration can be successfully implemented within the typical structures of high schools. In addition, future studies should also focus on students' experiences with integrated STEM, and how they interpret learning STEM in an integrated approach. Perhaps the students' beliefs and experiences could shed light on complementary or contrasting perspectives to their teachers' beliefs and experiences.

\section{Abbreviations}

AFNR: Agriculture, food, and natural resources; FFA: National Future Farmers of America Organization; STEM: Science, technology, engineering, and mathematics; TPD: Teacher professional development

\section{Acknowledgments}

Not applicable.

\section{Authors' contributions \\ HHW structured and organized the manuscript that includes writing the manuscript, data analysis. MC assisted literature reviews, methods, results, and discussions. NK and RT assisted data collection, discussion, and conclusions. All authors read and approved the final manuscript.}

\section{Funding}

This research was supported in part by the National Institute of Food and Agriculture (Hatch Project IND011778 and Project IND011778G).

\section{Availability of data and materials}

The datasets generated and/or analyzed during the current study are not publicly available due confidentiality and protection of rights of the human subjects, but are available from the corresponding author on reasonable request.

\section{Competing interests}

The authors declare that they have no competing interests.

\section{Author details}

${ }^{1}$ Department of Agricultural Sciences Education and Communication, Purdue University, 915 W. State Street, Lilly Hall, 3-223, West Lafayette, IN 47907, USA. ${ }^{2}$ Purdue University, 915 W. State Street, Lilly Hall, 4-401, West Lafayette, IN 47907, USA. ${ }^{3}$ Purdue University, 915 W. State Street, Lilly Hall, 3-232, West Lafayette, IN 47907, USA. ${ }^{4}$ Purdue University, 915 W. State Street, Lilly Hall, 2-119, West Lafayette, IN 47907, USA

Received: 12 March 2019 Accepted: 30 December 2019

Published online: 29 January 2020

\section{References}

Al Salami, M. K., Makela, C. J., \& de Miranda, M. A. (2015). Assessing changes in teachers' attitudes toward interdisciplinary STEM teaching. International Journal of Technology and Design Education, 27(1), 63-88 https://doi.org/10. 1007/s10798-015-9341-0.
Asghar, A., Ellington, R., Rice, E., Johnson, F., \& Prime, G. M. (2012). Supporting STEM education in secondary science contexts. Interdisciplinary Journal of Problem-Based Learning, 6(2), 85-125 https://doi.org/10.7771/1541-5015.1349.

Baker, M. A., Bunch, J. C., \& Kelsey, K. D. (2015). An instrumental case study of effective science integration in a traditional agricultural education program. Journal of Agricultural Education, 56(1), 221-236 https://doi.org/10.5032/jae. 2015.01221.

Bogdan, R. C., \& Biklen, S. K. (1998). Qualitative research for education: an introduction to theory and methods. Needham Heights: Allyn and Bacon.

Boyd, A. S. (2017). Social justice literacies in the English classroom: teaching practice in action. New York: Teachers College Press.

Breiner, J. M., Harkness, S. S., Johnson, C. C., \& Koehler, C. M. (2012). What is STEM? A discussion about conceptions of STEM in education and partnerships. School Science and Mathematics, 112(1), 3-11 https://doi.org/10.1111/j.19498594.2011.00109.x.

Bryan, L. A., Moore, T. J., Johnson, C. C., \& Roehrig, G. H. (2016). Integrated STEM education. In C. C. Johnson, E. E. Peters-Burton, \& T. J. Moore (Eds.), STEM road map: A framework for integrated STEM education (pp. 23-37). New York: Routledge.

Buehl, M. M., \& Alexander, P. A. (2001). Beliefs about academic knowledge. Educational Psychological Review, 13, 385-418 Retrieved from www.jstor.org/ stable/23363498

Buehl, M. M., \& Alexander, P. A. (2006). Examining the dual nature of epistemological beliefs. International Journal of Educational Research, 45, 2842 https://doi.org/10.1016/j.ijer.2006.08.007.

Buehl, M. M., \& Beck, J. S. (2014). The relationship between teachers' beliefs and teachers' practices. In H. Fives \& M. G. Gill (Eds.), International handbook of research on teachers' beliefs (pp. 66-84). New York: Routledge.

Bybee, R. W. (2010). Advancing STEM education: A 2020 vision. Technology and engineering teacher, 70(1), 30-35 Retrieved from https://search.proquest.com/ docview/853062675?accountid $=13360$

Bybee, R. W. (2013). A case for STEM education: challenges and opportunities. Arlington: National Science Teachers Association.

Cantrell, P., Pekcan, G., Itani, A., \& Velasquez-Bryant, N. (2006). The effects of engineering modules on student learning in middle school science classrooms. Journal of Engineering Education, 95(4), 301-309 https://doi.org/ 10.1002/j.2168-9830.2006.tb00905.x.

Capobianco, B. M., DeLisi, J., \& Radloff, J. (2017). Characterizing elementary teachers' enactment of high-leverage practices through engineering designbased science instruction. Science Education, 102(2), 342-376 https://doi.org/ $10.1002 /$ sce.21325.

Capraro, M. M., \& Jones, M. (2013). Interdisciplinary STEM project-based learning. In R. M. Capraro, M. M. Capraro, \& J. R. Morgan (Eds.), STEM project-based learning: An integrated science, technology, engineering, and mathematics (STEM) approach (pp. 51-58). Rotterdam: Sense Publishers.

Caudle, L. A., \& Moran, M. J. (2012). Changes in understandings of three teachers' beliefs and practice across time: Moving from teacher preparation to inservice teaching. Journal of Early Childhood Teacher Education, 33(1), 38-53 https://doi.org/10.1080/10901027.2011.650784.

Colburn, A. (2000). An inquiry primer. Science Scope, 23(6), 42-44 Retrieved from www.jstor.org/stable/43180086.

Creswell, J. W., Hanson, W. E., Plano Clark, V. L., \& Morales, A. (2007). Qualitative research designs: selection and implementation. The Counseling Psychologist, 35(2), 236-264 https://doi.org/10.1177/0011000006287390.

Donegan-Ritter, M. M., \& Zan, B. (2018). Designing and implementing inclusive STEM activities for early childhood. In I. Management Association (Ed.), K-12 STEM education: Breakthroughs in research and practice (pp. 839-866). Hershey: IGI Global https://doi.org/10.4018/978-1-5225-3832-5.ch040.

Drake, S. M., \& Burns, R. C. (2004). Meeting standards through integrated curriculum. Alexandria: Association for Supervision and Curriculum Development.

Dym, C. L., Agogino, A. M., Eris, O., Frey, D. D., \& Leifer, L. J. (2005). Engineering design thinking, teaching, and learning. Journal of Engineering Education, 94(1), 103-120 https://doi.org/10.1002/j.2168-9830.2005.tb00832.x.

English, L. D. (2016). STEM education K-12: Perspectives on integration. International Journal of STEM Education, 3(3), 1-8 https://doi.org/10.1186/ s40594-016-0036-1.

Fang, Z. (1996). A review of research on teacher beliefs and practices. Educational Research, 38(1), 47-65 https://doi.org/10.1080/0013188960380104.

Farrell, T. S., \& Ives, J. (2015). Exploring teacher beliefs and classroom practices through reflective practice: a case study. Language Teaching Research, 19(5), 594-610 https://doi.org/10.1177/1362168814541722. 
Flowers, N., Mertens, S. B., \& Mulhall, P. F. (1999). The impact of teaming: five research-based outcomes. Middle School Journal, 31(2), 57-60 https://doi.org/ 10.1080/00940771.1999.11494619.

Frykholm, J., \& Glasson, G. (2005). Connecting science and mathematics instruction: Pedagogical content knowledge for teachers. School Science and Mathematics, 105(3), 127-141 https://doi.org/10.1111/j.1949-8594.2005.tb18047.x

Gailey, J. D., \& Carroll, V. S. (1993). Toward a collaborative model for interdisciplinary teaching: business and literature. Journal of Education for Business, 69(1), 36-39 https://doi.org/10.1080/08832323.1993.10117653.

Graves, L. A., Hughes, H., \& Balgopal, M. M. (2016). Teaching STEM through horticulture: Implementing an edible plant curriculum at a STEM-centric elementary school. Journal of Agricultural Education, 57(3), 192-207 https:// doi.org/10.5032/jae.2016.03192.

Guzey, S. S., Ring-Whalen, E. A., Harwell, M., \& Peralta, Y. (2019). Life STEM: a case study of life science learning through engineering design. International Journal of Science and Mathematics Education, 17(1), 23-42 https://doi.org/10. 1007/s10763-017-9860-0.

Guzey, S. S., Tank, K. M., Wang, H. H., Roehrig, G. H., \& Moore, T. J. (2014). A highquality professional development for teachers of grades 3-6 for implementing engineering into classrooms. Journal of School Science and Mathematics, 114(3), 139-149 https://doi.org/10.1111/ssm.12061.

Hammack, R., \& Ivey, T. (2017). Examining elementary teachers' engineering selfefficacy and engineering teacher efficacy. School Science and Mathematics, 117(1-2), 52-62 https://doi.org/10.1111/ssm.12205.

Hargreaves, A., \& Moore, S. (2000). Curriculum integration and classroom relevance: a study of teacher's practice. Journal of Curriculum and Supervision, 15(2), 89-112 Retrieved from http://search.ebscohost.com.ezproxy.lib.purdue. edu/login.aspx?direct=true\&db=eue\&AN=507739368\&site=ehost-live.

Hofer, B. K. (2000). Dimensionality and disciplinary differences in personal epistemology. Contemporary Educational Psychology, 25, 378-405 https://doi. org/10.1006/ceps.1999.1026

Kelley, T. R., \& Knowles, J. G. (2016). A conceptual framework for integrated STEM education. International Journal of STEM Education, 3(1), 3-11 https://doi.org/ 10.1186/s40594-016-0046-Z.

Kendall, A. L., \& Wendell, K. B. (2012). Understanding the beliefs and perceptions of teachers who chose to implement engineering-based science instruction. San Antonio: Paper presented at the American Society for Engineering Education Annual Conference and Exposition.

Knobloch, N. A. (2008). Factors of teacher beliefs related to integrating agriculture into elementary school classroom. Agriculture and Human Values, 25(4), 529539. https://doi.org/10.1007/s10460-008-9135-z.

Kurup, P. M., Li, X., Powell, G., \& Brown, M. (2019). Building future primary teachers' capacity in STEM: based on a platform of beliefs, understandings and intentions. International Journal of STEM Education, 6(10). https://doi.org/ 10.1186/s40594-019-0164-5.

Lehman, J. R. (1994). Integrating science and mathematics: perceptions of preservice and practicing elementary teachers. Schoo/ Science and Mathematics, 94(2), 58-64 https://doi.org/10.1111/j.1949-8594.1994.tb12293.x.

Lesseig, K., Elliott, R., Kazemi, E., Kelly-Petersen, M., Campbell, M., Mumme, J., \& Carroll, C. (2017). Leader noticing of facilitation in videocases of mathematics professional development. Journal of Mathematics Teacher Education, 20(6), 591-619 https://doi.org/10.1007/s10857-016-9346-y.

Levy, S. (1992). Artificial life: a report from the frontier where computers meet biology. New York: Random House Inc.

Lim, C. P., \& Chai, C. S. (2008). Teachers' pedagogical beliefs and their planning and conduct of computer-mediated classroom lessons. British Journal of Educational Technology, 39(5), 807-828 https://doi.org/10.1111/j.1467-8535. 2007.00774.x

Liu, S.-H. (2011). Factors related to pedagogical beliefs of teachers and technology integration. Computers and Education, 56(4), 1012-1022 https:// doi.org/10.1016/j.compedu.2010.12.001

Lumpe, A. T., Haney, J. J., \& Czerniak, C. M. (2000). Assessing teachers' beliefs about their science teaching context. Journal of Research in Science Teaching, 37(3), 275-292 https://doi.org/10.1002/(sici)1098-2736(200003)37:3<275 :.:aidtea4>3.0.co;2-2.

Mansour, N. (2009). Science teachers' beliefs and practices: issues, implications and research agenda. International Journal of Environmental and Science Education, 4(1), 25-48 Retrieved from https://eric.ed.gov/?id=EJ884384.

Margot, K. C., \& Kettler, T. (2019). Teachers' perception of STEM integration and education: a systematic literature review. International Journal of STEM Education, 6(2). https://doi.org/10.1186/s40594-018-0151-2.
Mason, T. C. (1996). Integrated curricula: potential and problems. Journal of Teacher Education, 47(4), 263-270 https://doi.org/10.1177/0022487196474004.

McNeill, K. L., \& Knight, A. M. (2013). Teachers' pedagogical content knowledge of scientific argumentation: The impact of professional development on K-12 teachers. Science Education, 97(6), 936-972 https:// doi.org/10.1002/sce.21081.

Mehalik, M. M., Doppelt, Y., \& Schuun, C. D. (2008). Middle-school science through design-based learning versus scripted inquiry: better overall science concept learning and equity gap reduction. Journal of Engineering Education, 97(1), 71-85 https://doi.org/10.1002/j.2168-9830.2008.tb00955.x.

Moore, T. J., Stohlmann, M. S., Wang, H. H., Tank, K. M., Glancy, A. W., \& Roehrig, G. $H$. (2014). Implementation and integration of engineering in K-12 STEM education. In S. Purzer, J. Strobel, \& M. E. Cardella (Eds.), Engineering in precollege settings: Synthesizing research, policy, and practices. West Lafayette: Purdue University Press.

Murata, R. (2002). What does team teaching mean? A case study of interdisciplinary teaming. The Journal of Educational Research, 96(2), 67-77 https://doi.org/10.1080/00220670209598794.

National Academy of Engineering \& National Research Council. (2014). STEM integration in K-12 education: status, prospects, and an agenda for research. Washington, DC: The National Academies Press https://doi.org/ 10.17226/18612

National Research Council. (2012). A framework for K-12 science education: practices, crosscutting concepts, and core ideas. Washington, DC: The National Academies Press https://doi.org/10.17226/13165.

National Research Council. (2013). Next generation science standards: for states, by states. Washington, DC: The National Academics Press https://doi.org/10. $17226 / 18290$.

Nespor, J. (1987). The role of beliefs in the practice of teaching. Journal of Curriculum Studies, 19(4), 317-328 https://doi.org/10.1080/0022027870190403.

Pajares, M. F. (1992). Teachers' beliefs and educational research: cleaning up a messy construct. Review of Educational Research, 62(3), 307-332 https://doi. org/10.2307/1170741

Pang, J. S., \& Good, R. (2000). A Review of the Integration of Science and Mathematics: Implications for Further Research. School Science and Mathematics, 100(2), 73-82 https://doi.org/10.1111/j.1949-8594.2000.tb17239.x

Parr, B., \& Edwards, M. C. (2004). Inquiry-based instruction in secondary agricultural education: Problem-solving-An old friend revisited. Journal of Agricultural Education, 45(4), 106-117 https://doi.org/10.5032/jae.2004.04106.

Raymond, A. M. (1997). Inconsistency between a beginning elementary school teacher's mathematics beliefs and teaching practice. Journal for Research in Mathematics Education, 28(5), 550-576 https://doi.org/10.2307/749691.

Rice, A. H., \& Kitchel, T. (2017). Agriculture teachers' integrated belief systems and its influence on their pedagogical content knowledge. Journal of Agricultural Education, 59(1), 51-69 https://doi.org/10.5032/jae.2018.01059.

Richardson, K. A., Cilliers, P., \& Lissack, M. (2001). Complexity science: a "gray" science for the "stuff in between". Emergence, 3(2), 6-18 https://doi.org/10. 1207/s15327000em0302_02.

Saldaña, J. (2016). The coding manual for qualitative researchers (3rd ed.). Thousand Oaks: Sage Publications.

Schlechty, P. C. (1990). Schools for the 21st century: leadership imperative for educational reform. San Francisco: Jossey-Bass Publishers.

Sdunekv, A., \& Waitz, T. (2017). Algae: The green all-rounder-an interdisciplinary teaching unit for middle school students. Florence: Paper presented at the International Conference on the New Perspectives in Science Education.

Shapiro, E. J., \& Dempsey, C. J. (2008). Conflict resolution in team teaching: a case study in interdisciplinary teaching. College Teaching, 56(3), 157-162 https:// doi.org/10.3200/CTCH.56.3.157-162.

Shenton, A. K. (2004). Strategies for ensuring trustworthiness in qualitative research projects. Education for Information, 22(2), 63-75 https://doi.org/10. 3233/efi-2004-22201.

Smith, K. L., Rayfield, J., \& McKim, B. R. (2015). Effective practices in STEM integration: describing teacher perceptions and instructional method use. Journal of Agricultural Education, 56(4), 183-203 https://doi.org/10.5032/jae. 2015.04183.

St. Clair, B., \& Hough, D. L. (1992). Interdisciplinary teaching: a review of the literature. Retrieved from https://eric.ed.gov/?id=ED373056

Stake, R. E. (1994). Case studies. In N. K. Denzin \& Y. S. Lincoln (Eds.), Handbook of qualitative research (pp. 236-247). Thousand Oaks: Sage Publications.

Stake, R. E. (1995). The art of case study research. Thousand oaks: Sage Publications. 
Tuttle, N., Kaderavek, J. N., Molitor, S., Czerniak, C. M., Johnson-Whitt, E., Bloomquist, D., et al. (2016). Investigating the impact of NGSS-aligned professional development on preK-3 teachers' science content knowledge and pedagogy. Journal of Science Teacher Education, 27(7), 717-745 https:// doi.org/10.1007/s10972-016-9484-1.

Vasquez, J. A., Sneider, C., \& Comer, M. (2013). STEM lesson essentials: integrating science, technology, engineering, and mathematics. Portsmouth: Heinemann.

Wallace, J. J. (2007). Effects of interdisciplinary teaching team configuration upon the social bonding of middle school students. Research in Middle Level Education Online, 30(5), 1-18 https://doi.org/10.1080/19404476.2007. 11462038.

Wang, H. H., \& Knobloch, N. A. (2018). Levels of STEM integration through Agriculture, Food, and Natural Resources. Journal of Agricultural Education, 59(3), 258-277 https://doi.org/10.5032/jae.2018.03258.

Wang, H. H., Moore, T., Roehrig, G. H., \& Park, M. S. (2011). STEM integration: teacher perception and practice. The Journal of Pre-College Engineering Education Research, 1(2), 1-13 https://doi.org/10.5703/1288284314636.

Weinberg, A. E., \& McMeeking, L. B. S. (2017). Toward meaningful interdisciplinary education: high school teachers' views of mathematics and science integration. School Science and Mathematics, 117(5), 204-213 https://doi.org/ 10.1111/ssm.12224.

Yadav, A., \& Koehler, M. J. (2007). The role of epistemological beliefs in preservice teachers' interpretation of video cases of early-grade literacy instruction. Journal of Technology and Teacher Education, 15(3), 335-361 Retrieved from https://www.learntechlib.org/primary/p/20998/.

Yin, R. K. (2009). Case study research: Design and methods (4th ed.). Thousand Oaks: Sage Publications.

Yin, R. K. (2012). Applications of case study research (3rd ed.). Thousand Oaks: Sage Publications.

\section{Publisher's Note}

Springer Nature remains neutral with regard to jurisdictional claims in published maps and institutional affiliations.

\section{Submit your manuscript to a SpringerOpen ${ }^{\circ}$ journal and benefit from:}

- Convenient online submission

- Rigorous peer review

- Open access: articles freely available online

- High visibility within the field

- Retaining the copyright to your article

Submit your next manuscript at $\boldsymbol{\nabla}$ springeropen.com 